\title{
Combined Ion-Mobility and Mass-Spectrometry Investigations of Metallothionein Complexes Using a Tandem Mass Spectrometer with a Segmented Second Quadrupole
}

\author{
Yuzhu Guo, Yun Ling, ${ }^{+}$Bruce A. Thomson, ${ }^{*}$ and K. W. Michael Siu \\ Department of Chemistry and Center for Research in Mass Spectrometry, York University, \\ Toronto, Ontario, Canada
}

\begin{abstract}
Rabbit metallothionein (MT) 2A complexes with Cd(II), Zn(II), Ag(I), Cu(I), Hg(II), arsenite, monomethylarsonous acid (MMA), and dimethylarsinous acid (DMA) have been examined using ion-mobility measurements and mass spectrometry in a triple-quadrupole mass spectrometer equipped with a segmented second quadrupole that doubled as an ion-mobility cell [Guo, Y.; Wang, J.; Javahery, G.; Thomson, B. A.; Siu, K. W. M. An Ion-Mobility Spectrometer with Radial Collisional Focusing. Anal. Chem. 2005, 77, 266-275]. The metal ions confer conformational rigidity on the MT complexes, which counteracts Coulombic repulsion among protons added as a result of electrospray. Triply and quadruply protonated $\mathrm{Cd}_{7} \mathrm{MT} 2 \mathrm{~A}$ have smaller cross-sections than the $\mathrm{Cd}_{7} \mathrm{MT} 2 \mathrm{~A}$ structure deduced from published NMR data. For the $6+$ ions, the $\mathrm{As}_{6} \mathrm{MT} 2 \mathrm{~A}$ complex has a cross-section of $790 \AA^{2}$; the $\mathrm{MMA}_{10} \mathrm{MT} 2 \mathrm{~A}$ complex, $920 \AA^{2}$; and the $\mathrm{DMA}_{20} \mathrm{MT} 2 \mathrm{~A}$ complex, $1220 \AA^{2}$. This increase in cross-section of the As(III) species, from $\mathrm{As}^{3+}$ to MMA to DMA, is interpreted as a consequence of decreasing multiple coordination and increasing number of methyl groups. (J Am Soc Mass Spectrom 2005, 16, 1787-1794) @ 2005 American Society for Mass Spectrometry
\end{abstract}

I on mobility, $K$, is a measure of the ion's effective size by virtue of its collision cross-section, $\Omega_{T}$, at temperature $T$, with a given buffer gas, typically helium, under the influence of a weak electric field. Provided that the number density of the buffer gas, $N$, is sufficiently high and the imposed electric field, $E$, is sufficiently low, the drift velocity, $v_{d}$, is proportional to $E$ with $K$ being the proportionality constant.

$$
v_{d}=K E
$$

$\Omega_{T}$ can be determined from $K$ using the Mason-Schamp equation $[1,2]$ :

$$
\Omega_{T}=\left(\frac{3 z e}{16 N}\right)\left(\frac{2 \pi}{\mu k T}\right)^{1 / 2}\left(\frac{1}{K}\right)
$$

where $z$ is the numerical charge, $e$ is the elementary charge, $\mu$ is the reduced mass of the ion and helium, and $k$ is the Boltzmann's constant.

Published online September 22, 2005

Address reprint requests to Professor K. W. Michael Siu, Department of Chemistry and Center for Research in Mass Spectrometry, York University, 4700 Keele Street, Toronto, Ontario M3J 1P3, Canada. E-mail: kwmsiu@yorku.ca

* Also at MDS SCIEX, Concord, Ontario, Canada.

${ }^{+}$Current address: Department of Chemistry, University of British Columbia, Vancouver, British Columbia, Canada.
The collision cross-section of an ion is one of the most readily measurable, albeit somewhat crude, structure-related parameter that has come under close scrutiny in the last decade or so. Coupled to comparisons with theoretical cross-sections calculated from probable structures found by optimizations using molecular dynamics and first-principle methods, measurements of $\Omega_{T}$ have allowed insights into three-dimensional structures of peptides and proteins in the gas-phase [3-5].

Ion-mobility measurements are typically made in drift tubes at atmospheric or subatmospheric pressure containing a stack of ring electrodes which maintain a constant electric field in the axial direction [6]. Highresolution operation requires the use of high (nearatmospheric) pressure and high voltages; the need for high pressure in the drift tube necessitates the use of small apertures in interfacing with the mass- analyzer region of the spectrometer (which requires lowpressure operation) and leads to radial diffusion because of increased ion residence time. This combination typically results in modest sensitivity. Recently, we reported construction and testing of an ion-mobility spectrometer that has its mobility cell as a 20-segment rf-only quadrupole and functionally the second quadrupole (q2) of a triple-quadrupole mass spectrometer [7]. The characteristics of high cell pressure (maximum of 4 torr of helium) and low axial field (20-160 V/20.2 $\mathrm{cm})$ meant that there was negligible internal excitation 
of the ions, despite applications of $\mathrm{rf}$ and axial fields. In addition, the presence of collisional focusing ensured efficient ion transmission and good sensitivity. Indeed, most measurements were made with solutions containing $10 \mu \mathrm{M}$ peptides and proteins [7], concentrations typical of electrospray experiments.

Metallothioneins (MTs) are small cysteine-rich proteins that typically comprise some 60 amino acid residues, many of which are serine and threonine and none being aromatic residues [8-10]. In mammals, MTs are typically induced in the liver after an influx of heavy metals, which is believed to be a means of detoxification. Some of the most examined MTs are from the rabbit, which expresses at least six known isoforms. The MT-2A isoform has 62 amino acid residues; of these 20 are cysteines, eight serines and three threonines [8-10]. Many mono- and divalent metals have been observed to complex with MTs, including $\mathrm{Cu}(\mathrm{I}), \mathrm{Ag}(\mathrm{I}), \mathrm{Zn}(\mathrm{II})$, $\mathrm{Cd}(\mathrm{II})$, and $\mathrm{Hg}$ (II) [11-14]. Recently, As(III), in the forms of arsenite, monomethylarsonous acid (MMA), and dimethylarsinous acid (DMA), has also been observed to bind with MTs [15]. Traditionally, methylation of arsenic is believed to be a detoxification process [16, 17]. However, MMA and DMA are at least as toxic as arsenite [18-22], although their pentavalent forms are considerably less so [16, 17].

Rabbit MT2A binds up to seven $\mathrm{Zn}^{2+}$ and $\mathrm{Cd}^{2+}$ ions in a cooperative fashion. The seven divalent metal ions, in forming metal-thiolate bonds, formally displace 14 cysteinyl protons in the MT molecule. The remaining six cysteinyl $\mathrm{S}$ atoms and many of the serinyl $\mathrm{O}$ atoms also participate in binding. The first 31 residues constitute the $\beta$ domain, which binds three $\mathrm{Zn}^{2+}$ or $\mathrm{Cd}^{2+}$ ions with a stoichiometry of $\mathrm{M}_{3} \mathrm{~S}_{9}$, while the remaining residues form the $\alpha$ domain, which binds four metal ions with a stoichiometry of $\mathrm{M}_{4} \mathrm{~S}_{11}$ [11]. Cd- and Zncontaining MT2A complexes have been examined using a variety of techniques, including electrospray mass spectrometry (MS), which unambiguously reveals the overall binding stoichiometry. MT binding to other metal ions is comparatively less well characterized. Binding of up to $19 \mathrm{Ag}^{+}$has been observed using electrospray MS [14]. Circular dichroism (CD) studies gave evidence to the existence of the $\mathrm{Ag}_{12}-\mathrm{MT}$ and $\mathrm{Ag}_{17}$-MT complexes; these complexes were also observed in the electrospray MS experiment, but so were other complexes containing 13-19 $\mathrm{Ag}^{+}$[14]. Similarly, $\mathrm{CD}$ apparently supported existence of the $\mathrm{Cu}_{12}-\mathrm{MT}$ complex. Recently, trivalent arsenicals were reported to bind with MTs [15]. Up to six arsenite, $10 \mathrm{MMA}$, and 20 DMA were observed to bind with MT2A using electrospray MS [15].

Cooperative binding between the metal ions and the cysteine and other residues confers conformational rigidity to the metal-MT complex. Many studies in the last decade have proven that the conformations of electrosprayed proteins in the gas-phase do reflect their solution structures, but are subject to perturbations due to removal of water and enhancement of electrostatic interactions, including those from protons that are attached during the electrospray process [5, 23]. The Coulombic repulsion between the protons attached tends to destabilize the metal-MT complex and has an opposing effect to cooperative binding. Here we report results of an examination, using combined ion mobility and MS, of the intricate interplay between cooperative binding and Coulombic repulsion on metallated MTs as a model system.

\section{Experimental}

\section{Instrumentation}

The ion-mobility apparatus was built from custom parts and components of the API 3000 triple-quadrupole mass spectrometer (MDS SCIEX). Details of this instrument have been published [7]. Briefly, Q1 and Q3 are conventional MS analyzers; however, the q2 is a 20segment quadrupole/ion-mobility cell and is physically isolated in its own chamber from the Q1 and Q3 chambers that are at much lower pressure (Figure 1). The segments are held in place and insulated from each other within a Delrin housing. A $1.26 \mathrm{MHz} 400 \sim 750 \mathrm{~V}$ (peak-to-peak) rf potential is applied to each segment for efficient ion transmission and collisional focusing. Typical mobility measurements were conducted with an axial field of $40-100 \mathrm{~V}(\Delta \mathrm{U})$ over $20.2 \mathrm{~cm}$ in 1 torr of helium, giving an E/N value of 6-15 Td at $298 \mathrm{~K}$. For consistency, all mobility spectra shown in this report were acquired under an axial field of $40.0 \mathrm{~V} / 20.2 \mathrm{~cm}$ and a helium pressure of 1.05 torr.

For ion-mobility measurements, ions were injected into q2 by employing IQ2 as an ion gate. Ions were normally barred by biasing IQ2 to $70 \mathrm{~V}$. To inject ions, IQ2 was lowered to $-130 \mathrm{~V}$ for $50 \mu \mathrm{s}$. Ion injection was typically repeated every $4-20 \mathrm{~ms}$. The output of the detector was fed to a multichannel scaler to permit

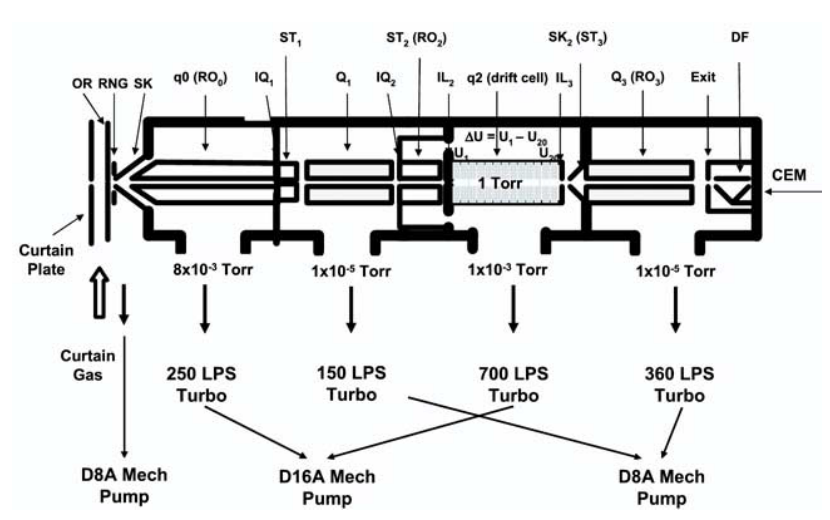

Figure 1. Diagram of the tandem mass spectrometer with a segmented q2 doubling as the ion-drift cell: q0, rf-only quadrupole; $\mathrm{Q} 1$ and $\mathrm{Q} 3$, quadrupole mass filters; $\mathrm{IQ}_{1}$ and $\mathrm{IQ}_{2}$, electrostatic ion lenses; $\mathrm{IL}_{2}$ and $\mathrm{IL}_{3}$, entrance and exit lenses, respectively, of the ion-drift cell; $\mathrm{ST}_{1}$ and $\mathrm{ST}_{2}$, short rf-only quadrupoles; $\mathrm{SK}_{2}$, skimmer for Q3 (biased electrically as $\mathrm{ST}_{3}$ ); Q2, drift cell; $\mathrm{U}_{1}$ and $\mathrm{U}_{20}$, dc offsets on the first and last (20th) segments; $\Delta \mathrm{U}$, potential difference across the drift cell. 
recording of the arrival times $\left(t_{a}\right)$ of the ions. $t_{a}$ were measured at different $\Delta U$ with constant $t_{f}$ and at a time resolution of 5-10 $\mu \mathrm{s}$. Typically, 500-5000 raw spectra were summed to improve signal/noise. The orifice potential (OR) determined the initial extent of collisional heating of the sampled ions. The OR value was optimized and fixed for a given set of experiments.

\section{Materials}

Rabbit liver metallothionein II $\left(\mathrm{Zn}_{7} \mathrm{MT} 2 \mathrm{~A}\right.$ or $\left.\mathrm{Cd}_{7} \mathrm{MT} 2 \mathrm{~A}\right)$, chemicals and HPLC-grade water were purchased from Sigma-Aldrich (St. Louis, MO). For mobility measurements, MT2A solutions were 5-10 $\mu \mathrm{M}$ in water. For $\mathrm{pH}$ adjustment, $0.3 \%$ formic acid (or 10 $\mathrm{mM}$ TFA), $2 \mathrm{mM}$ ammonium acetate, and $20 \mathrm{mM}$ ammonia were added to achieve $\mathrm{pH}$ ca. 3, 6, and 9, respectively. $\mathrm{AgNO}_{3}, \mathrm{Cu}\left(\mathrm{CH}_{3} \mathrm{COO}\right), \mathrm{Cd}\left(\mathrm{CH}_{3} \mathrm{COO}\right)_{2}$, $\mathrm{Hg}\left(\mathrm{CH}_{3} \mathrm{COO}\right)_{2}$, and $\mathrm{NaAsO}_{2}$ were used as sources for $\mathrm{Ag}(\mathrm{I}), \mathrm{Cu}(\mathrm{I}), \mathrm{Cd}(\mathrm{II}), \mathrm{Hg}(\mathrm{II})$, and arsenite. MMA and DMA were synthesized following published procedures [24, 25]. Oxidized apoMT2A was prepared by adding $\mathrm{Cu}\left(\mathrm{CH}_{3} \mathrm{COO}\right)_{2}$ to $\mathrm{Cd}_{7} \mathrm{MT} 2 \mathrm{~A}$ solution in $1 \%$ formic acid to achieve a final concentration of 15 and 10 $\mu \mathrm{M}$, respectively; the resulting solution was allowed to stand for $\sim 20 \mathrm{~h}$.

\section{Ionization Methods}

Multiply protonated MT2A and its metal complexes were generated from their respective solutions by means of pneumatically assisted electrospray (ionspray) at a typical flow rate of $1-2 \mu \mathrm{L} / \mathrm{min}$. The optimal nebulizer gas setting was typically 3 to 5 . As some of the compounds investigated are toxic, e.g., acute toxicity onsets for $\mathrm{Hg}$ (II) and $\mathrm{As}(\mathrm{III})$ are $2 \mathrm{mg}$ per $\mathrm{kg}$ of body weight (MSDS), caution was exercised to ensure that the ionspray source was properly sealed and vented. Any materials that came into contact with the ion source contents and ion lens, e.g., gloves and swabs used in cleaning, were presumed contaminated and disposed of accordingly. The maximum daily consumption of all samples was under $1 \mathrm{~mL}$. Even for the highest salt concentrations, e.g., $0.5 \mathrm{mM} \mathrm{Hg}$ (II) and $2.0 \mathrm{mM} \mathrm{As}(\mathrm{III})$, the maximum daily consumption was $0.10 \mathrm{mg}$ of $\mathrm{Hg}$ (II) or $0.15 \mathrm{mg}$ of $\mathrm{As}(\mathrm{III})$, assuming that only $\mathrm{Hg}(\mathrm{II})$ or As(III) was examined that day.

\section{Data Analysis}

Ion mobilities $(K)$ and collision cross-sections $\left(\Omega_{T}\right)$ were derived from the measured $t_{a}$ :

$$
t_{a}=t_{d}+t_{f}=\frac{L^{2}}{K \Delta \mathrm{U}}+t_{f}
$$

where $t_{d}$ is drift time, the time that ions spent drifting in $\mathrm{q} 2 ; t_{f}$ is the time that ions spent in flight from q2 to the detector; and $L$ is the length of the segmented quadru- pole (drift cell). At constant $t_{f}$, a set of measurements of $t_{a}$ under different $\Delta \mathrm{U}$ gives a straight line when $t_{a}$ are plotted against $1 / \Delta \mathrm{U}$. $K$ was obtained from the slope, and $\Omega_{T}$ from eq 2 . Theoretical fitting of ion mobility spectra was performed using a modified version of the software ATCAL provided by R. R. Hudgins and M. F. Jarrold. ATCAL calculates the diffusion coefficient, $D$, from $K$ via the Einstein equation [1].

\section{Cross-Section Predictions from Available Structures}

The collision cross-section of neutral $\mathrm{Cd}_{7} \mathrm{MT} 2 \mathrm{~A}$ was calculated in an effort to compare it with measured cross-sections of metallated MT2A complexes. The $\alpha$ and $\beta$ domain structures were obtained from Protein Data Bank [26]. Two collision cross-section prediction models, projection [27] and trajectory [28], were employed. Software for calculations based on these models was obtained under MOBCAL courtesy of M. F. Jarrold [29].

\section{Results and Discussion}

\section{Cd-and Zn-MT2A Complexes}

In accordance with previous findings [30-32], the number of metal ions bound by MT is a function of the solution $\mathrm{pH}$. Figure $2 \mathrm{a}$ illustrates this for the Cd-MT2A complex: at a $\mathrm{pH}$ of 9 , the $\mathrm{Cd}_{7} \mathrm{MT} 2 \mathrm{~A}$ complex was observed. Three $\mathrm{Cd}^{2+}$ ions were lost upon acidification to $\mathrm{pH}$ 6. Lowering of the $\mathrm{pH}$ to 3 resulted in the loss of all $\mathrm{Cd}^{2+}$ ions. It is noteworthy that only the following species exist: $\mathrm{Cd}_{7} \mathrm{MT} 2 \mathrm{~A}, \mathrm{Cd}_{4} \mathrm{MT} 2 \mathrm{~A}$, and apoMT2A, which contains no metal ions. These results are consistent with the interpretation that MT2A binds $\mathrm{Cd}^{2+}$ cooperatively in two domains, $\alpha$ and $\beta$, which incorporate, respectively, four and three metal ions. Apparently, binding in the $\beta$ domain is weaker, which results in displacement of the three $\mathrm{Cd}^{2+}$ by $\mathrm{H}^{+}$ions upon acidification to $\mathrm{pH}$ 6. Further addition of acid results in displacement of the remaining four $\mathrm{Cd}^{2+}$ ions in the $\alpha$ domain by protons, thus resulting in metal-free MT, apoMT2A.

Electrospraying of the Cd-MT2A complex results in proton attachment, as shown in Figure $2 a$. Figure $2 b$ and $c$ display relevant windows of the arrival-time distributions (ion-mobility spectra) in units of crosssection [1, 2, 7] for different charge states of the $\mathrm{Cd}_{7} \mathrm{MT} 2 \mathrm{~A}$ complex and apoMT2A. The $\left[\mathrm{Cd}_{7} \mathrm{MT} 2 \mathrm{~A}+\right.$ $3 \mathrm{H}]^{3+}$ ion exhibits two distinct distributions at 610 and $755 \AA^{2}$. The peak widths of the distributions are wider than the width of a peak in which band-broadening is attributable solely to diffusion (simulated distributions based only on diffusion are shown as dash lines) [1]. As previously observed, the possibility exists that one or both of these distributions may contain unresolved conformations (of similar cross-sections) [7]. By contrast, the $\left[\mathrm{Cd}_{7} \mathrm{MT} 2 \mathrm{~A}+4 \mathrm{H}\right]^{4+}$ ion has apparently only 
(a)

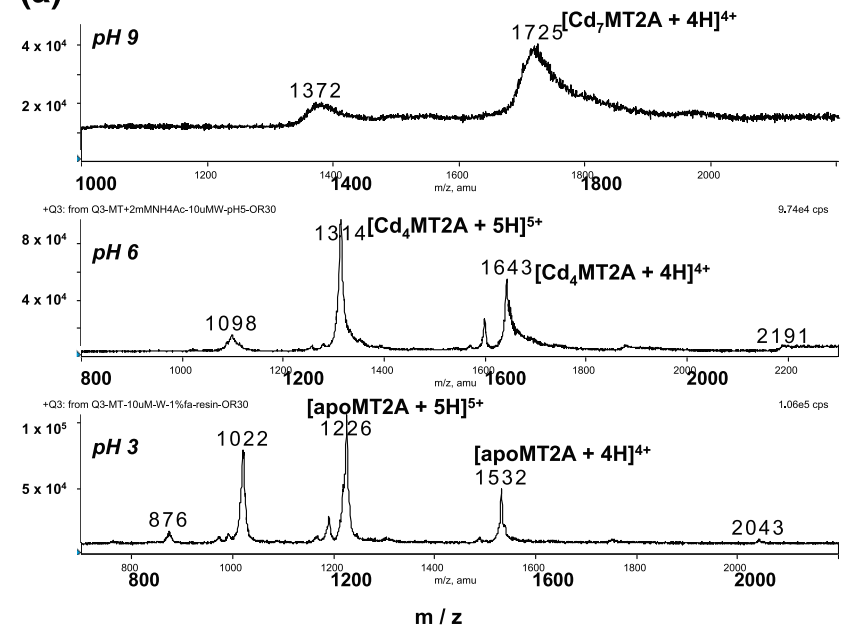

(c)

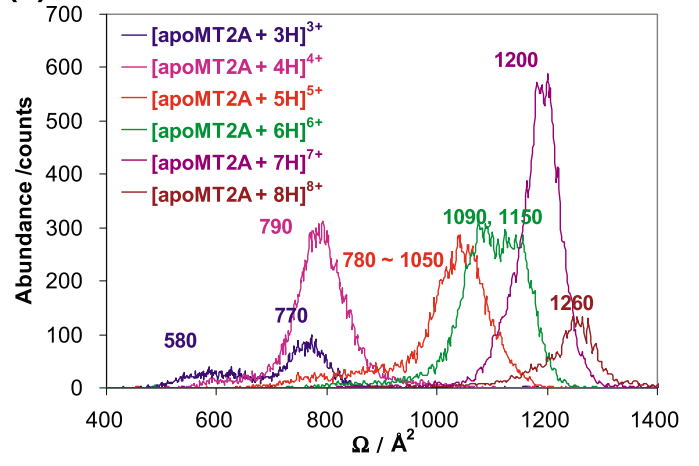

(b)

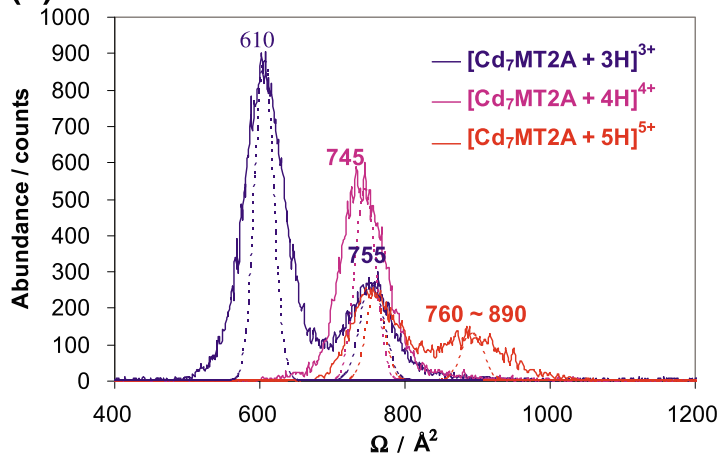

(d)

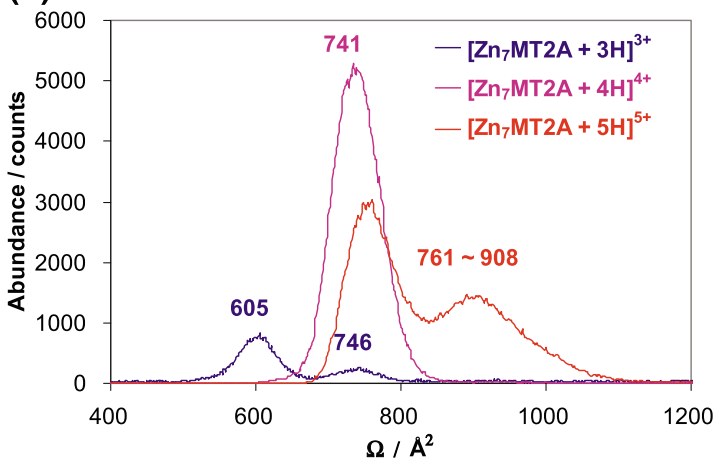

Figure 2. Cd-MT2A complexes: (a) electrospray mass spectra of $\mathrm{Cd}_{7} \mathrm{MT} 2 \mathrm{~A}$ at different $\mathrm{pH}$ conditions: $\mathrm{pH} 9$, in $20 \mathrm{mM} \mathrm{NH}_{3}$; $\mathrm{pH} 6$ in $2 \mathrm{mM}$ ammonium acetate; $\mathrm{pH} 3$ in $1 \%$ formic acid; (b) arrival-time distributions (ion-mobility spectra) in units of cross-section for $\left[\mathrm{Cd}_{7} \mathrm{MT} 2 \mathrm{~A}+3 \mathrm{H}\right]^{3+},\left[\mathrm{Cd}_{7} \mathrm{MT} 2 \mathrm{~A}+\right.$ $4 \mathrm{H}]^{4+}$, and $\left[\mathrm{Cd}_{7} \mathrm{MT} 2 \mathrm{~A}+5 \mathrm{H}\right]^{5+}$; the dashed lines show theoretical distributions in which bandbroadening is due only to diffusion; (c) arrival-time distributions in units of cross-section for the $3+$ to $8+$ ions of apoMT2A; (d) arrival-time distributions in units of cross-section for $\left[\mathrm{Zn}_{7} \mathrm{MT} 2 \mathrm{~A}+3 \mathrm{H}\right]^{3+}$, $\left[\mathrm{Zn}_{7} \mathrm{MT} 2 \mathrm{~A}+4 \mathrm{H}\right]^{4+}$, and $\left[\mathrm{Zn}_{7} \mathrm{MT} 2 \mathrm{~A}+5 \mathrm{H}\right]^{5+}$.

one distinct conformation at $745 \AA^{2}$. Again, the $\left[\mathrm{Cd}_{7} \mathrm{MT} 2 \mathrm{~A}+5 \mathrm{H}\right]^{5+}$ ion displays two distinct conformations at 760 and $890 \AA^{2}$. The average precision of cross-sectional measurements on our apparatus is $\pm 2 \%$; the three similar cross-sections, 745,755 , and $760 \AA^{2}$, are within the limits of experimental error. Within the context of cross-sectional data, there is a minimum of three distinct conformations of protonated $\mathrm{Cd}_{7} \mathrm{MT} 2 \mathrm{~A}$ with cross-sections of 610,750 , and $890 \AA^{2}$. The $\mathrm{Cd}_{4}$ MT2A complex also exhibits a minimum of three distinct conformations with cross-sections similar to those of $\mathrm{Cd}_{7} \mathrm{MT} 2 \mathrm{~A}$ (arrival-time distributions not shown). The trend of increasing cross-section with charge is consistent with earlier observations and interpretation that increasing charge increases the extent of Coulombic repulsion and results in a more extended conformation $[3,5,7,33,34]$. This trend is also apparent for the apoMT2A ions; increasing charge results in opening up of the apoMT2A structure from $580 \AA^{2}$ of the $3+$ ion to $1260 \AA^{2}$ of the $8+$ ion. Comparing ions of the same charge, e.g., $4+, \mathrm{Cd}_{7} \mathrm{MT} 2 \mathrm{~A}$ has a cross-section of $745 \AA^{2}$ versus apoMT2A's $790 \AA^{2}$, a decrease of $6 \%$. For the $5+$ ion, $\mathrm{Cd}_{7} \mathrm{MT} 2 \mathrm{~A}$ has a cross-section of $890 \AA^{2}$ versus apoMT2A's $1090 \AA^{2}$, which is a much larger decrease of $18 \%$. Apparently, binding of MT to Cd ions counteracts Coulombic repulsion between the protons, results in more compact conformations, and manifests as smaller cross-sections. Binding of $\mathrm{Zn}^{2+}$ to MT2A shows a strong parallel with that of $\mathrm{Cd}^{2+}$. However, the binding is weaker as evidenced by displacement of $\mathrm{Zn}^{2+}$ by $\mathrm{Cd}^{2+}$ in a solution of Zn-MT2A complex and $\mathrm{Cd}^{2+}$. The arrival-time distributions of $\left[\mathrm{Zn}_{7} \mathrm{MT} 2 \mathrm{~A}+\right.$ $3 \mathrm{H}]^{3+},\left[\mathrm{Zn}_{7} \mathrm{MT} 2 \mathrm{~A}+4 \mathrm{H}\right]^{4+}$ and $\left[\mathrm{Zn}_{7} \mathrm{MT} 2 \mathrm{~A}+5 \mathrm{H}\right]^{5+}$ are shown in Figure $2 \mathrm{~d}$. The cross-sections of these ions are similar to those of their counterparts in $\mathrm{Cd}_{7} \mathrm{MT} 2 \mathrm{~A}$.

Structural details of the $\alpha$ and $\beta$ binding domains of $\mathrm{Cd}_{7} \mathrm{MT} 2 \mathrm{~A}$ as measured in solution using nuclear magnetic resonance spectrometry (NMR) are available from the Protein Data Bank [26]. To arrive at an estimate of the collision cross-section of $\mathrm{Cd}_{7} \mathrm{MT} 2 \mathrm{~A}$, we arbitrarily joined the $\mathrm{N}$-terminus of the $\alpha$ to the $\mathrm{C}$-terminus of the $\beta$ domain in three ways. After adding hydrogen to the resulting 
structures, the theoretical collision cross-sections were determined. The average cross-sections obtained using the projection [27] and the trajectory [28] models were $891 \pm$ 16 ( \pm one standard deviation) and $1067 \pm 25 \AA^{2}$, respectively. Our previous results on bradykinin ions show that measured cross-sections fall between those predicted with the projection and the trajectory models [7]. The measured cross-sections of the $\left[\mathrm{Cd}_{7} \mathrm{MT} 2 \mathrm{~A}+3 \mathrm{H}\right]^{3+}$ and $\left[\mathrm{Cd}_{7} \mathrm{MT} 2 \mathrm{~A}\right.$ $+4 \mathrm{H}]^{4+}$ ions are smaller than, while that of the $\left[\mathrm{Cd}_{7} \mathrm{MT} 2 \mathrm{~A}+5 \mathrm{H}\right]^{5+}$ ion is comparable to or slightly smaller than, the measured cross-section of the $\mathrm{Cd}_{7} \mathrm{MT} 2 \mathrm{~A}$ structure according to NMR determinations [26]. Gasphase protein structures of low charges that are more compact than "native" structures have previously been reported for bovine pancreatic trypsin inhibitor and cytochrome $c$ [33].

\section{$\mathrm{Ag}-\mathrm{Cu}$, and $\mathrm{Hg}-\mathrm{MT} 2 \mathrm{~A}$ Complexes}

Binding of $\mathrm{Ag}^{+}, \mathrm{Cu}^{+}$, and $\mathrm{Hg}^{2+}$ to MT2A is different from that of $\mathrm{Cd}^{2+}$ and $\mathrm{Zn}^{2+}$. Figure 3 a shows electrospray mass spectra of solutions at $\mathrm{pH} 3$ containing $\mathrm{Ag}^{+}$ and MT2A in different ratios. At an $\mathrm{Ag}^{+}: \mathrm{MT}$ ratio of 5:1, little $\mathrm{Ag}^{+}$binding is evident. Further increase of the $\mathrm{Ag}^{+}$:MT ratio results in $\mathrm{Ag}^{+}$incorporation: at a ratio of 10:1, $\mathrm{Ag}_{8-16}$ MT2A complexes are apparent; and at 20:1, the predominant species is $\mathrm{Ag}_{19} \mathrm{MT} 2 \mathrm{~A}$, which is in accordance with a previous report [14]. The ions observed are $5+$ and $6+$ in charge (the $4+$ ion being more apparent in $10 \mathrm{mM}$ TFA solutions). MT2A comprises 20 cysteine residues. $\mathrm{Ag}^{+}$is a soft acid and, in solution, prefers binding to soft bases such as $-\mathrm{S}^{-}$or $-\mathrm{SH}$ [35]. The mass accuracy of our mass spectrometer, at \pm 0.5 $\mathrm{Th}$, is insufficient to determine exactly how many of the cysteine residues exist formally as $-\mathrm{S}^{-}$or $-\mathrm{SH}$. For the $5+$ ion, this translates to \pm 3 hydrogens. We are assuming that the $19 \mathrm{Ag}$ replace 19 of the cysteine sulfhydryl hydrogens. However, ionization by (multiple) $\mathrm{Ag}^{+}$attachment on peptides and proteins has been observed [36], and it is possible that up to three of the $19 \mathrm{Ag}$ are attached, i.e., exist formally as $\mathrm{Ag}^{+}$as opposed to Ag-S-.

The arrival-time distributions for the $\left[\mathrm{Ag}_{19} \mathrm{MT} 2 \mathrm{~A}+\right.$ $4 \mathrm{H}]^{4+},\left[\mathrm{Ag}_{19} \mathrm{MT} 2 \mathrm{~A}+5 \mathrm{H}\right]^{5+}$, and $\left[\mathrm{Ag}_{19} \mathrm{MT} 2 \mathrm{~A}+6 \mathrm{H}\right]^{6+}$ ions are shown in Figure $3 \mathrm{~b}$. The collision cross-sections are, respectively, 744, 746, and $940 \AA^{2}$. The $4+$ and 5+ complexes of $\mathrm{Ag}_{19} \mathrm{MT} 2 \mathrm{~A}$ are compact; addition of the 6th proton opens up the complex to a more extended conformation (a residue of the more compact conformation is also discernible). In a separate experiment, the $\mathrm{Ag}_{4} \mathrm{MT} 2 \mathrm{~A}$ complex was more abundantly produced following $\mathrm{Ag}$ substitution of $\mathrm{Cd}$ in $\mathrm{Cd}_{7} \mathrm{MT} 2 \mathrm{~A}$ and acidification to $\mathrm{pH}$ 2. The arrival-time distributions for the $\left[\mathrm{Ag}_{4} \mathrm{MT} 2 \mathrm{~A}+4 \mathrm{H}\right]^{4+},\left[\mathrm{Ag}_{4} \mathrm{MT} 2 \mathrm{~A}+5 \mathrm{H}\right]^{5+}$, and $\left[\mathrm{Ag}_{4} \mathrm{MT} 2 \mathrm{~A}+6 \mathrm{H}\right]^{6+}$ ions are shown in Figure 3c. The $\left[\mathrm{Ag}_{4} \mathrm{MT} 2 \mathrm{~A}+4 \mathrm{H}\right]^{4+}$ ion exhibits two distinct conformations at 591 and $754 \AA^{2}$ with the former being the most compact of conformations seen thus far. However, the more highly charged ions of the $\mathrm{Ag}_{4} \mathrm{MT} 2 \mathrm{~A}$ complex are

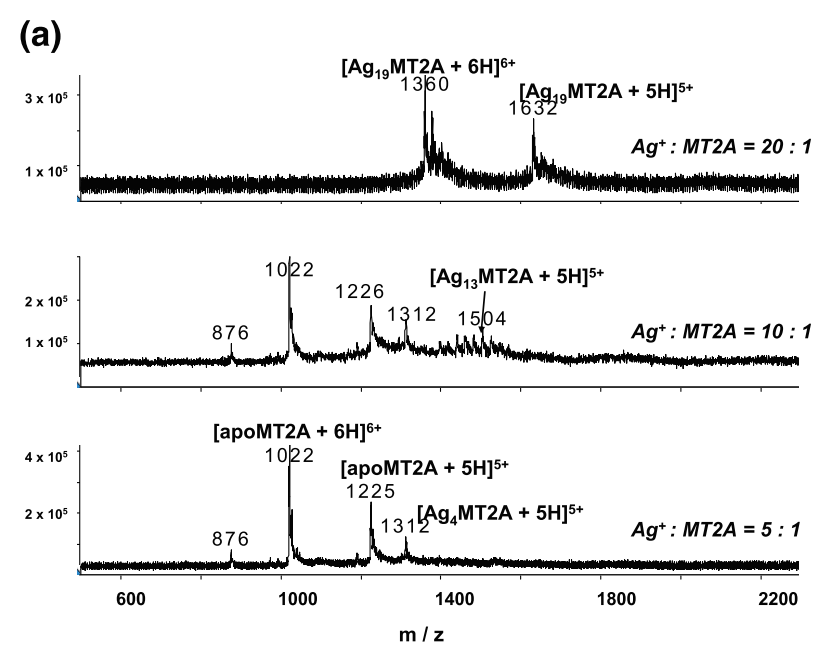

(b)

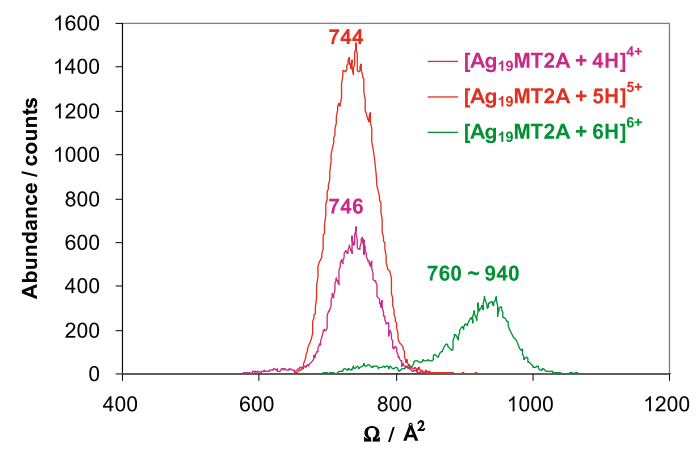

(c)

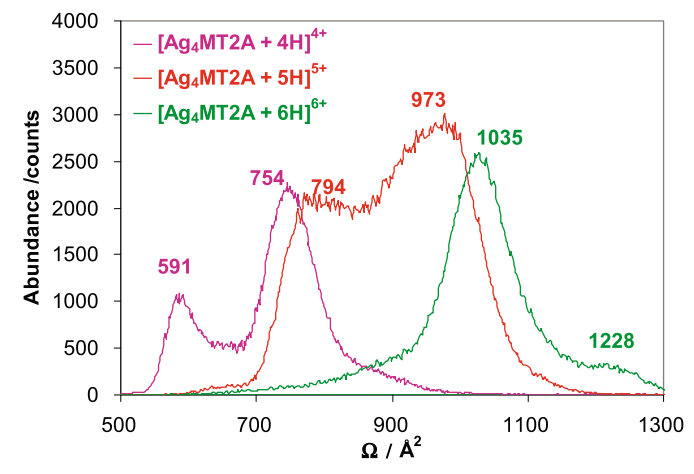

Figure 3. Ag-MT2A complexes: (a) electrospray mass spectra of solutions containing different ratios of $\mathrm{Ag}^{+}$to MT2A, protein concentration being $10 \mu \mathrm{M}$ in $0.3 \%$ formic acid, $\mathrm{pH} 3$; (b) arrivaltime distributions for $\left[\mathrm{Ag}_{19} \mathrm{MT} 2 \mathrm{~A}+4 \mathrm{H}\right]^{4+},\left[\mathrm{Ag}_{19} \mathrm{MT} 2 \mathrm{~A}+5 \mathrm{H}\right]^{5+}$, and $\left[\mathrm{Ag}_{19} \mathrm{MT} 2 \mathrm{~A}+6 \mathrm{H}\right]^{6+}$; (c) arrival-time distributions for $\left[\mathrm{Ag}_{4} \mathrm{MT} 2 \mathrm{~A}+4 \mathrm{H}\right]^{4+},\left[\mathrm{Ag}_{4} \mathrm{MT} 2 \mathrm{~A}+5 \mathrm{H}\right]^{5+}$, and $\left[\mathrm{Ag}_{4} \mathrm{MT} 2 \mathrm{~A}+\right.$ $6 \mathrm{H}]^{6+}$.

all comparatively more extended than the $\mathrm{Ag}_{19} \mathrm{MT} 2 \mathrm{~A}$ ions of the same charge. Evidently, relative to $\mathrm{Ag}_{19} \mathrm{MT} 2 \mathrm{~A}$, the fewer metal ions in $\mathrm{Ag}_{4} \mathrm{MT} 2 \mathrm{~A}$ translate to a structure of lower conformational rigidity, which expands more easily in the presence of comparable Coulombic repulsion attributable to addition of protons. The cross-sections of the $\left[\mathrm{Cu}_{4} \mathrm{MT} 2 \mathrm{~A}+4 \mathrm{H}\right]^{4+}$, $\left[\mathrm{Cu}_{4} \mathrm{MT} 2 \mathrm{~A}+5 \mathrm{H}\right]^{5+}$, and $\left[\mathrm{Cu}_{4} \mathrm{MT} 2 \mathrm{~A}+6 \mathrm{H}\right]^{6+}$ ions, at 740, 770, 910, and $970 \AA^{2}$ (arrival-time distributions not shown), are all slightly smaller than those of the 
$\left[\mathrm{Ag}_{4} \mathrm{MT} 2 \mathrm{~A}+4 \mathrm{H}\right]^{4+},\left[\mathrm{Ag}_{4} \mathrm{MT} 2 \mathrm{~A}+5 \mathrm{H}\right]^{5+}$, and $\left[\mathrm{Ag}_{4} \mathrm{MT} 2 \mathrm{~A}+6 \mathrm{H}\right]^{6+}$ ions, consistent with the smaller van der Waals radius of $\mathrm{Cu}(1.4 \AA)$ compared to that of $\operatorname{Ag}(1.72 \AA)$ [37].

Figure 4a shows electrospray mass spectra of solutions at $\mathrm{pH} 3$ containing $\mathrm{Hg}^{2+}$ and MT2A in different ratios. It is evident that at a $\mathrm{Hg}^{2+}$ :MT ratio of $1: 1$, the most prominent complexes are $\mathrm{Hg}_{5} \mathrm{MT} 2 \mathrm{~A}$ and $\mathrm{Hg}_{6}$ MT2A. At a $\mathrm{Hg}^{2+}$ :MT ratio of 5:1, additional $\mathrm{Hg}^{2+}$ incorporation results in the complexes $\mathrm{Hg}_{7} \mathrm{MT} 2 \mathrm{~A}$ and

\section{(a)}
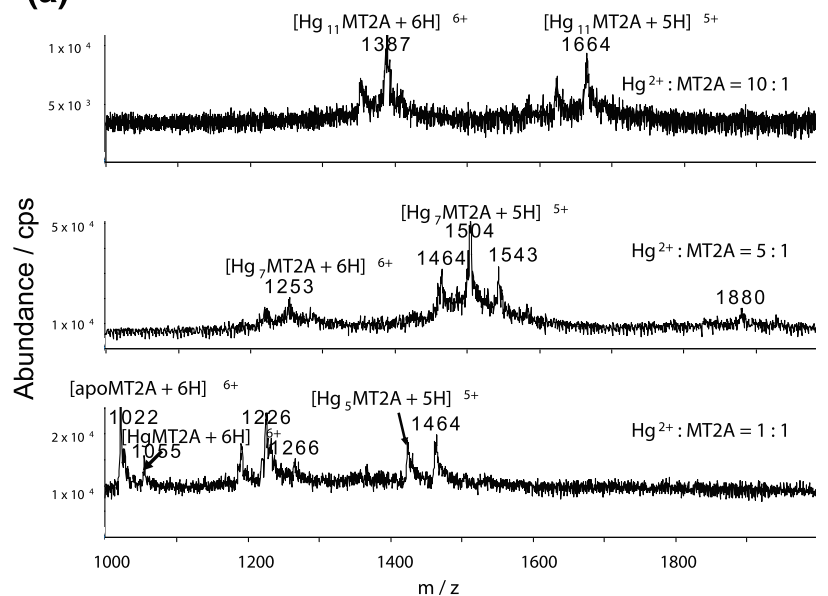

(b)

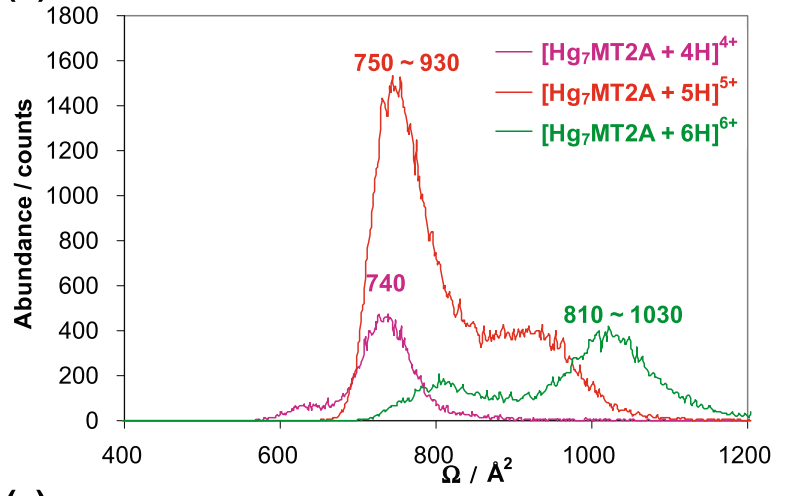

(c)

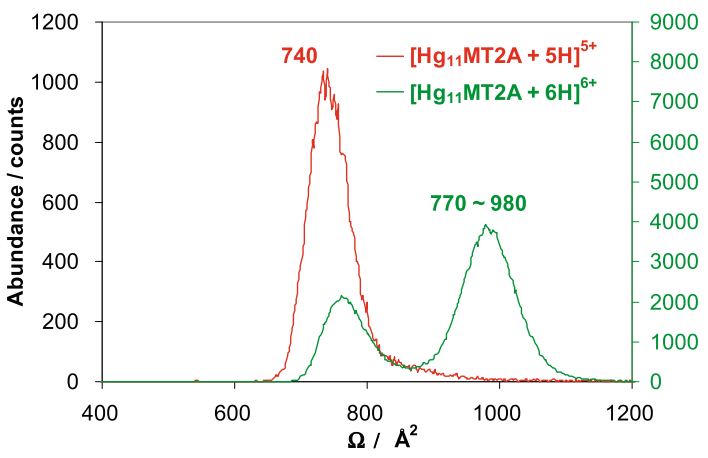

Figure 4. Hg-MT2A complexes: (a) electrospray mass spectra of solutions containing different ratios of $\mathrm{Hg}^{2+}$ to MT2A, protein concentration being $5 \mu \mathrm{M}$ in $0.3 \%$ formic acid, $\mathrm{pH} 3$; (b) arrivaltime distributions for $\left[\mathrm{Hg}_{7} \mathrm{MT} 2 \mathrm{~A}+4 \mathrm{H}\right]^{4+},\left[\mathrm{Hg}_{7} \mathrm{MT} 2 \mathrm{~A}+5 \mathrm{H}\right]^{5+}$, and $\left[\mathrm{Hg}_{7} \mathrm{MT} 2 \mathrm{~A}+6 \mathrm{H}\right]^{6}{ }^{+}$; (c) arrival-time distributions for $\left[\mathrm{Hg}_{11} \mathrm{MT} 2 \mathrm{~A}+5 \mathrm{H}\right]^{5+}$ and $\left[\mathrm{Hg}_{11} \mathrm{MT} 2 \mathrm{~A}+6 \mathrm{H}\right]^{6+}$.

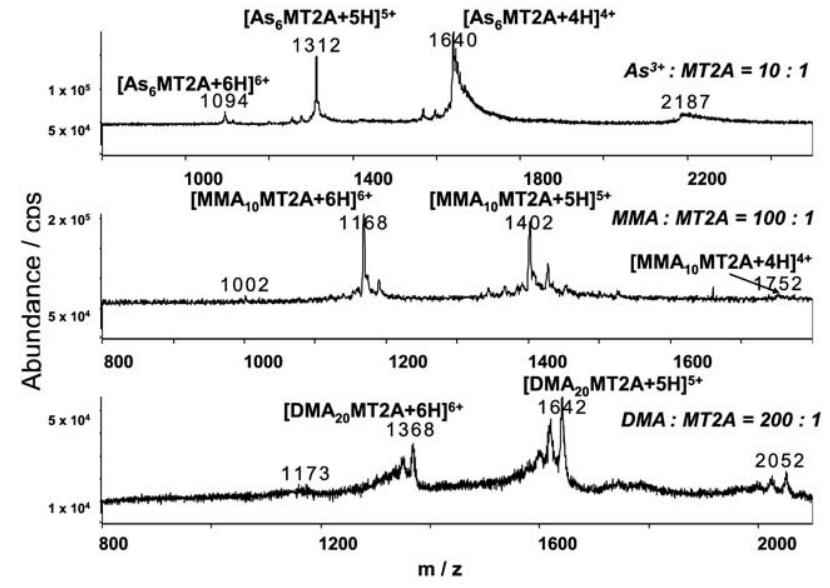

Figure 5. Electrospray mass spectra of $\mathrm{As}^{3+}, \mathrm{MMA}$, and DMA with MT2A to achieve maximum metal binding: $10 \mu \mathrm{M}$ MT2A in $0.3 \%$ formic acid, $\mathrm{pH} 3$.

$\mathrm{Hg}_{8}$ MT2A. Further increase of the ratio to 10:1 leads to $\mathrm{Hg}_{10} \mathrm{MT} 2 \mathrm{~A}$ and $\mathrm{Hg}_{11} \mathrm{MT} 2 \mathrm{~A}$. Figure $4 \mathrm{~b}$ and $\mathrm{c}$ shows the arrival-time distributions of the $4+, 5+$, and $6+$ ions of, respectively, $\mathrm{Hg}_{7} \mathrm{MT} 2 \mathrm{~A}$ and $\mathrm{Hg}_{11} \mathrm{MT} 2 \mathrm{~A}$. The $\left[\mathrm{Hg}_{7} \mathrm{MT} 2 \mathrm{~A}+4 \mathrm{H}\right]^{4+}$ and $\left[\mathrm{Hg}_{11} \mathrm{MT} 2 \mathrm{~A}+4 \mathrm{H}\right]^{4+}$ ions have identical cross-sections of $740 \AA^{2}$ (the arrival-time distribution of the latter is not shown). Addition of the 5 th and the 6th protons results in expansion of the ions, but to different extents. Apparently, the presence of four extra $\mathrm{Hg}$ in $\mathrm{Hg}_{11}$ MT2A affords the complex additional rigidity and results in smaller conformations.

\section{As-, $M M A^{-}$, and DMA-MT2A Complexes}

Figure 5 shows the mass spectra of $\mathrm{As}^{3+}, \mathrm{MMA}$, and DMA with MT2A. The maximum numbers of arsenic species bound by MT are: $\mathrm{As}^{3+}$, 6; MMA, 10; and DMA, 20; in accordance with previous observation [15]. The presence of the methyl groups affects binding with MT2A, which translates into changes in the crosssection. Take the $4+$ ions, the $\mathrm{As}_{6} \mathrm{MT} 2 \mathrm{~A}$ complex has a cross-section of $750 \AA^{2}$; the $\mathrm{MMA}_{10} \mathrm{MT} 2 \mathrm{~A}$ complex, 800 $\AA^{2}$; and the $\mathrm{DMA}_{20} \mathrm{MT} 2 \mathrm{~A}$ complex, 960 and $1150 \AA^{2}$. The increase in cross-section from the $\mathrm{As}^{3+}$ to MMA to DMA complex can be interpreted as a decrease in "cross-linking" $\left(\mathrm{As}^{3+}\right.$ binds to three cysteinyl S $\mathrm{S}^{-}, \mathrm{MMA}$ two, and DMA only one) [15] and/or an increase in the cross-section of the individual arsenic species due to increasing number of methyl groups. Similarly, for the $6+$ ions, the $\mathrm{As}_{6} \mathrm{MT} 2 \mathrm{~A}$ complex gives a cross-section of $790 \AA^{2}$; the $\mathrm{MMA}_{10} \mathrm{MT} 2 \mathrm{~A}$ complex, $920 \AA^{2}$; and the $\mathrm{DMA}_{20} \mathrm{MT} 2 \mathrm{~A}$ complex, $1220 \AA^{2}$.

The binding of $\mathrm{As}(\mathrm{III})\left[\mathrm{As}^{3+}, \mathrm{MMA}\right.$, and DMA] to MT2A differs from those of other metal species in that it progresses smoothly from $1 \mathrm{As}(\mathrm{III})$ to the maximum. The abundances of all intermediate species are sufficiently high for measurement and experimentation. Figure 6 shows the arrival-time distributions of the $6+$ ion of the MMA ${ }_{n}$ MT2A complex for $n=0-10$. The 


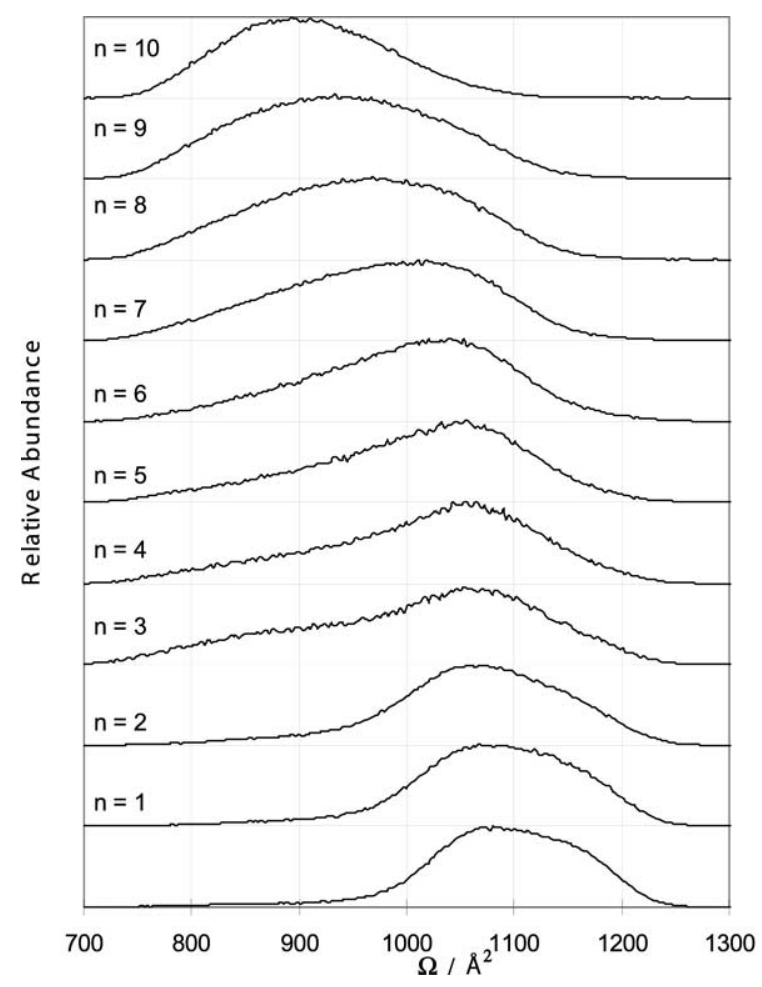

Figure 6. Arrival-time distributions for $\left[\mathrm{MMA}_{\mathrm{n}} \mathrm{MT} 2 \mathrm{~A}+6 \mathrm{H}\right]^{6+}$, $n=1-10: 10 \mu \mathrm{M}$ MT2A in $0.3 \%$ formic acid, $\mathrm{pH} 3$.

stabilizing effect on the complex conformation via MMA binding is evidenced by the decrease in arrival time from ca. 4.40 to $3.65 \mathrm{~ms}\left(1090\right.$ to $900 \AA^{2}$ for $n=$ $0-10$, in corroboration with observations in other metal MT2A complexes.

\section{Oxidized MT2A}

Oxidized apoMT2A, o-apoMT2A, was prepared by demetalating $\mathrm{Cd}_{7} \mathrm{MT} 2 \mathrm{~A}$ in a $1 \%$ formic acid solution

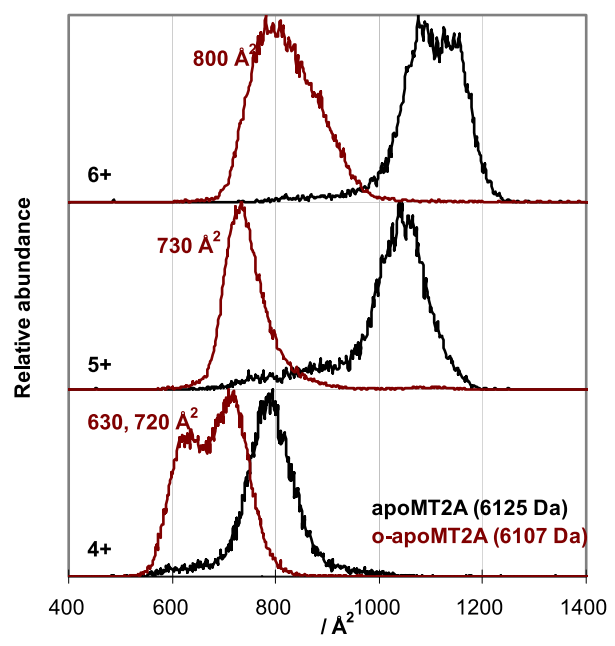

Figure 7. Arrival-time distributions for the $4+$ to $6+$ ions of apoMT2A and oxidized apoMT2A: $10 \mu \mathrm{M}$ MT2A in $0.3 \%$ formic acid, $\mathrm{pH} 3$. and oxidizing with $\mathrm{Cu}^{2+}$. The resulting protein has a measured mass of ca. 18 Da lower than apoMT2A. In addition, the cross-sections of the ions are much smaller than those of apoMT2A (Figure 7). These observations strongly suggest that o-apoMT2A is extensively crosslinked, most likely via formation of disulfide bridges. The $4+, 5+$, and $6+$ ions have cross-sections of 630 and 720,730 , and $800 \AA^{2}$, comparatively smaller than those of $\mathrm{Cd}_{7} \mathrm{MT} 2 \mathrm{~A}$ and $\mathrm{As}_{6} \mathrm{MT} 2 \mathrm{~A}$ with the same charges. Conceptually, metal-binding by MT introduces crosslinking; the -S-M-S- bonds created are expected to be longer than the $-\mathrm{S}-\mathrm{S}-$ bond formed in o-apoMT2A. This view is in accordance with the observation of comparatively more compact o-apoMT2A ions than $\mathrm{Cd}_{7} \mathrm{MT} 2 \mathrm{~A}$ and $\mathrm{As}_{6} \mathrm{MT} 2 \mathrm{~A}$ ions.

\section{Conclusions}

All observations support the notion that metal binding in MT confers conformational rigidity that opposes Coulombic repulsion. This stabilizing effect is greater when the number of metal ions bound is higher, presumably attributable to more extensive cross-linking.

\section{Acknowledgments}

The authors thank Drs. Robert R. Hudgins, Alan C. Hopkinson, and Vladimir I. Baranov for insightful discussion, and Drs. X. Chris Le and William R. Cullen for instructions on syntheses of MMA and DMA. This research was supported by the Natural Sciences and Engineering Research Council (NSERC) of Canada, MDS SCIEX, and York University. Parts of this work were presented at the 52nd ASMS Conference, Nashville, TN, May 23-27, 2004.

\section{References}

1. Mason, E. A.; McDaniel, E. W. Transport Properties of Ions in Gases; John Wiley and Sons: New York, 1988.

2. Revercomb, H. E.; Mason, E. A. Theory of Plasma Chromatography/Gaseous Electrophoresis. Anal. Chem. 1975, 47, 970983.

3. Clemmer, D. E.; Hudgins, R. R.; Jarrold, M. F. Naked Protein Conformations: Cytochrome $c$ in the Gas Phase. J. Am. Chem. Soc. 1995, 117, 10141-10142.

4. Wyttenbach, T.; von Helden, G.; Bowers, M. T. Gas-Phase Conformation of Biological Molecules: Bradykinin. J. Am. Chem. Soc. 1996, 118, 8355-8364.

5. Hoaglund-Hyzer, C. S.; Counterman, A. E.; Clemmer, D. E. Anhydrous Protein Ions. Chem. Rev. 1999, 99, 3037-3079.

6. McDaniel, E. W.; Mason, E. A. The Mobility and Diffusion of Ions in Gases; John Wiley and Sons: New York, 1973; pp 51-84, and references therein.

7. Guo, Y.; Wang, J.; Javahery, G.; Thomson, B. A.; Siu, K. W. M. An Ion Mobility Spectrometer with Radial Collisional Focusing. Anal. Chem. 2005, 77, 266-275.

8. Kagi, J. H. R.; Kojima, Y., Eds. Metallothionein II; Birkhauser Verlag: Basel, Germany, 1987.

9. Stillman, M. J.; Shaw, C. F., III; Suzuki, K. T., Eds. Metallothioneins: Synthesis, Structure, and Properties of Metallothioneins, Phytochelatins and Metal-Thiolate Complexes; VCH: New York, 1992. 
10. Suzuki, K. T.; Imura, N.; Kimura, M., Eds. Metallothionein III; Birkhauser Verlag: Basel, Germany, 1993.

11. Arseniev, A.; Schultze, P.; Worgotter, E.; Braun, W.; Wagner, G.; Vasak, M.; Kagi, J. H.; Wuthrich, K. Three-Dimensional Structure of Rabbit Liver [Cd7] Metallothionein-2A in Aqueous Solution Determined by Nuclear Magnetic Resonance. J. Mol. Biol. 1988, 201, 637-657.

12. Stillman, M. J.; Presta, A.; Gui, Z.; Jiang, D.-T. Spectroscopic Studies of Copper, Silver, and Gold-Metallothioneins. MetalBased Drugs 1994, 1, 375-393.

13. Li, H.; Otvos, J. D. HPLC Characterization of $\mathrm{Ag}^{+}$and $\mathrm{Cu}^{+}$ Metal Exchange Reactions with $\mathrm{Zn}$ - and Cd-Metallothioneins. Biochemistry 1996, 35, 13937-13945.

14. Stillman, M. J. Spectroscopic Studies of Copper and Silver Binding to Metallothioneins. Metal-Based Drugs 1999, 6, 277290.

15. Jiang, G.; Gong, Z.; Li, X.-F.; Cullen, W. R.; Le, X. C. Interaction of Trivalent Arsenicals with Metallothionein. Chem. Res. Toxicol. 2003, 16, 873-880.

16. Yamauchi, H.; Fowler, B. A. Toxicity and Metabolism of Inorganic and Methylated Arsenicals. In Arsenic in the Environment, Part II: Human Health and Ecosystem Effects; Nriagu, J. O., Ed.; Wiley: New York, 1994; pp 35-43.

17. Goyer, R. A. Toxic Effects of Metals. In Casarett and Doull's Toxicology: The Basic Science of Poisons, 5th ed.; Klaassen, C. D., Ed.; McGraw-Hill: New York, 1996; pp 696-698.

18. Styblo, M.; Serves, S. V.; Cullen, W. R.; Thomas, D. J. Comparative Inhibition of Yeast Glutathione Reductase by Arsenicals and Arsenothiols. Chem. Res. Toxicol. 1997, 10, 27-33.

19. Lin, S.; Cullen, W. R.; Thomas, D. J. Methylarsenicals and Arsinothiols are Potent Inhibitors of Mouse Liver Thioredoxin Reductase. Chem. Res. Toxicol. 1999, 12, 924-930.

20. Petrick, J. S.; Ayala-Fierro, F.; Cullen, W. R.; Carter, D. E.; Aposhian, H. V. Monomethylarsonous Acid (MMA $\left.{ }^{\mathrm{III}}\right)$ is More Toxic Than Arsenite in Chang Human Hepatocytes. Toxicol. Appl. Pharmacol. 2000, 163, 203-207.

21. Petrick, J. S.; Bhumasamudram, J.; Mash, E. A.; Aposhian, H. V. Monomethylarsonous Acid $\left(\mathrm{MMA}^{\mathrm{III}}\right)$ and Arsenite: $\mathrm{LD}_{50}$ in Hamsters and In Vitro Inhibition of Pyruvate Dehydrogenase. Chem. Res. Toxicol. 2001, 14, 651-656.

22. Mass, M. J.; Tennant, A.; Roop, R. C.; Cullen, W. R.; Styblo, M.; Thomas, D. J.; Kligerman, A. D. Methylated Trivalent Arsenic Species are Genotoxic. Chem. Res. Toxicol. 2001, 14, 355-361.
23. Loo, J. A. Studying Noncovalent Protein Complexes by Electrospray Ionization Mass Spectrometry. Mass Spectrom. Rev. 1997, 16, 1-23.

24. Cullen, W. R.; McBride, B. C.; Manji, H.; Pickett, A. W.; Reglinski, J. The Metabolism of Methyarsine Oxide and Sulfide. Appl. Organomet. Chem. 1989, 3, 71-78.

25. Burrows, G. J.; Turner, E. E. A New Type of Compound Containing Arsenic. J. Chem. Soc. Trans. 1920, 117, 1373-1383.

26. Protein Data Bank. Website at http://www.rcsb.org/pdb/.

27. von Helden, G.; Hsu, M. T.; Gotts, N. G.; Bowers, M. T. Carbon Cluster Cations with Up to 84 Atoms: Structures, Formation Mechanism, and Reactivity. J. Phys. Chem. 1993, 97, 8182-8192.

28. Mesleh, M. F.; Hunter, J. M.; Shvartsburg, A. A.; Schatz, G. C.; Jarrold, M. F. Structural Information from Ion Mobility Measurements: Effect of the Long-Range Potential. J. Phys. Chem. 1996, 100, 16082-16086.

29. Jarrold, M. F. Website at http://nano.chem.indiana.edu/ software.html.

30. Yu, X.; Wojciechowski, M.; Fenselau, C. Assessment of Metals in Reconstituted Metallothioneins by Electrospray Mass Spectrometry. Anal. Chem. 1993, 65, 1355-1359.

31. Le Blanc, J. C. Y. Use of Ionspray Mass Spectrometry in the Speciation and Elemental Characterization of Metallothioneins. J. Anal. At. Spectrom. 1997, 12, 525-530.

32. Guo, X.; Chan, H. M.; Guevremont, R.; Siu, K. W. M. Analysis of Metallothioneins by Means of Capillary Electrophoresis Coupled to Electrospray Mass Spectrometry with Sheathless Interface. Rapid Commun. Mass Spectrom. 1999, 13, 500-507.

33. Shelimov, K. B.; Clemmer, D. E.; Hudgins, R. R.; Jarrold, M. F. Protein Structure In Vacuo: Gas-Phase Conformations of BPTI and Cytochrome c. J. Am. Chem. Soc. 1997, 119, 2240-2248.

34. Wittmer, D. P.; Chen, Y. H.; Luckenbill, B. K.; Hill, H. H., Jr. Electrospray Ionization Ion Mobility Spectrometry. Anal. Chem. 1994, 66, 2348-2355.

35. Glusker, J. P. Structural Aspects of Metal Liganding to Functional Groups in Proteins. Adv. Protein Chem. 1991, 42, 1-76.

36. Li, H.; Siu, K. W. M.; Guevremont, R.; Le Blanc, J. C. Y. Complexes of Silver(I) with Peptides and Proteins as Produced in Electrospray Mass Spectrometry. J. Am. Soc. Mass Spectrom. 1997, 8, 781-792.

37. Biondi, A. van der Waals Volumes and Radii. J. Phys. Chem. 1964, 68, 441-451. 